\title{
Determinants of Climate Change Risk Management Strategies Among the Aquaculture Fish Farmers in Nigeria Using Multinomial Logit Model
}

\author{
Olaniran. Anthony Thompson* Sadiat Funmilayo Arifalo Adekunle. Adegoke Atejioye \\ Department of Agricultural and Resource Economics, The Federal University of Technology, \\ P. M. B. 704, Akure, Nigeria
}

\begin{abstract}
Nigeria's domestic supply of fishery products falls short of the demand; however, there is a growing aquaculture industry that has come to the rescue in filling the gap between supply and demand. The aquaculture fish farmers are prone to the risk of climate change, since weather and extreme events have become more unpredictable. This study assessed the climate change risk management strategies among the aquaculture fish farmers' in Southwest Nigeria. Multi-stage sampling technique was used to select 480 aquaculture fish farmers' in the study area. Descriptive statistics, likert scale and multinomial logit model were used to analyze the data. The study revealed that all the respondents were aware that climate is changing. The commonly used adaptation strategy by the fish farmers in the area was use of concrete /plastic pond (78\%). The result of the multinomial logit model revealed that farm income influences the adoption of flood control/provision of water outlet by $19.22 \%$, provision of alternative water supply (Well/Borehole) by $45.11 \%$ and the use of the concrete/plastic pond by $18.89 \%$. Flood control/provision of water outlet, providing alternative water supply (Well/Borehole), use of concrete /plastic pond are all investment that were positively significant at $1 \%$. Therefore, increase in farm income will lead to increase in these adaptation strategies to mitigate the effects of climate change on fish production in the study area. The study recommends that government at all levels should provide loan at a single digit interest rate to mitigate the effects of climate change on aquaculture fish farming.
\end{abstract}

Keywords: Climate change; Fish farmers; Risk management strategies; Multinomial logit model, Southwest Nigeria

DOI: $10.7176 / \mathrm{JEES} / 11-2-06$

Publication date: February $28^{\text {th }} 2021$

\section{Introduction}

Nigeria is certainly a food deficit nation (Olukoya, 2016) and it is obvious that protein intake is grossly inadequate in both qualitative and quantitative terms. Although, fish is generally regarded as a cheap source of animal protein (Federal Department of Fisheries, (FDF), 2018), the shortfall in domestic production due to the neglect of the subsector and climate change risk effects on fish production has resulted in an increase in importation of fish in Nigeria (Fagbenro et al., 2014). However, there is a growing aquaculture industry that has come to the rescue to fill the gap between supply and demand because of its profitability (Kareem et al, 2016). The available data on aquaculture attest to this fact. In 1990, aquacultures' contribution to total fish production was $2.3 \%$ and by 2017 , its contribution has increased to $21.7 \%$ (FDF, 2018).

Furthermore, agriculture in the form of crop production, livestock breeding, fishery and forestry is the primary sector of the economy of Nigeria, accounting for employment for majority of the Nigerian population (Oyetade \& Applanaidu, 2014). About $80 \%$ of the country's poor people live in rural areas and work primarily in agriculture. About $25 \%$ of Nigeria's Gross Domestic Products (GDP) comes from agriculture and related activities, and close to $70 \%$ of the national labour force is employed in agriculture, $10 \%$ in manufacturing industry and mining, and $20 \%$ in services. So, Nigeria's economy is therefore predominantly agrarian; agriculture remains the driving force for the country's economic development (Olukoya, 2016).

Again, most of the empirical works to date on the effects of climate change on agricultural sector have focused on crops and livestock (Intergovernmental Panel on Climate Change (Thompson, 2017). Most physical and economic modelling and analyses have focused on the northern latitudes and high-income countries to the neglect of the developing low-income countries like Nigeria (Niyongabire \& Rhinane, 2019). Furthermore, scientists' fear that most of the adverse effects of climate change is likely to occur in these poorer countries, such as Nigeria. The effects of climate change urgently need to be assessed at the level of the aquaculture fish farmers', so that poor and vulnerable aquaculture fish farmers' whose livelihood dependent on fish farming can be appropriately targeted in research and development activities for poverty alleviation. This is with the aim of providing meaningful insight and contributing to efforts aimed at formulating policies at all tiers of government in order to ensure increased food availability through sustainable domestic fish production and increased income from fish production such as aquaculture fish farming in Nigeria.

Hence, findings of this study will assist the traditional aquaculture fish farmers' in Nigeria toiling daily to 
provide food for subsistence and cash to improve their purchasing power. They will also be guided on the adaptation strategies to mitigate the effects of climate change. Also, the findings will equally provide the expected back-up data to be used by planners and policies makers at all tiers of government. Therefore, the study intends to find out the fish farmers awareness of climate change and their perceived effects of climate change on fish production in the study area. The adaptation strategies used by the fish farmers to mitigate perceived effects of climate change on fish production and the factors that influence the adaptation strategies used by the fish farmers in the study area was also determined in the study. This is to enhance the formulation of efficient and effective policies that will mitigate the effects of climate change risk on the aquaculture fish farmers' productivity in Southwest Nigeria.

\subsection{Conceptual Framework}

The conceptual framework of the study was based on bio-psychological point of view. According to Coon and Mitterer, (2013) "human perception is the final part of a complex psychophysical process. At first, information from the environment (e.g., temperature, sun, humidity and rainfall) activates a person's sense receptors in sensory organs. Then, through transduction process, the sense receptors convert the physical energy from stimulus into electrical signals called neural impulses and send them to the brain. When neural impulses reach the particular area in the brain, they are changed into meaningless bits of information called sensation, which involves the detection of sensory stimuli". These meaningless bits of information are finally changed into meaningful and complete images called perception (Krull, 2014).

Prior knowledge and experience help the brain interpret a certain stimulus positively or negatively. This fundamental process is at the root of human understanding of environmental big issues like global warming. Studies of human behavior indicate that the performance of a behavior is "a joint function of intentions and perceived behavioral control" (Abrahmse, 2019). Thus, the link between how people perceive risk and then act on it is a construct. Cultural adherence and social learning can frame the perception of climate change risks (NurseyBray et al., 2012). Perceptions of events and phenomena are conditioned by values, which vary according to local bodies (Boholm, 1998). This implies that people from different cultures may perceive climate change risks differently. Thus, cultural theory of risks can foresee and explain 'what kind of people will perceive which potential hazards to be how dangerous' (Dake \& Wildavsky, 1990).

Since Climate is a dynamic phenomenon that changes continually, with long-term warming and cooling cycles. According to Intergovernmental Panel on Climate Change (IPCC), 2010) recent rapid and extensive changes are too extreme to be dismissed as 'normal', and have been shown to be closely correlated to changes in atmospheric carbon as a result of human activities. It has been established in the review of crop, livestock and fisheries systems in Africa, Nigeria inclusive that the links between agriculture and climate are quite pronounced and often complex (Shikha, 2018). Climate change risk transmits to the agricultural sector via unpredictable increase in rainfall which usually result in flood, unpredictable reduction in rainfall which result in drought and excessive increase in temperature that enhance drought and low humidity resulting from human activities (Food and Agriculture Organization (FAO), 2018).

Hence most farmers' perceived climate is changing from their perception of change in rainfall pattern that they perceived is increasing excessively leading to flood or reducing excessively leading to drought. Also, they complement their perception with change in temperature pattern which may be increasing or reducing. Therefore, according to Dechassa et al., (2020) an average farmer perceived climate change from the perceptive of change in rainfall, change in temperature, and change in humidity. Climate change risk to aquaculture fish farmers' in the study area is presented schematically in figure 1 . Risk because of climate change as perceived by an aquaculture fish farmers' in the study area from the figure emanates from change in rainfall pattern which may result in flood or drought. These climate change phenomena may have a positive or negative impact on fish farming in the study area as perceived by the fish farmers' (DFID, 2014). From the findings as shown in the figure, climate change risk management strategies among the aquaculture fish farmers' in Southwest Nigeria are flood control/provision of water outlet, providing alternative water supply (Well/borehole), planting trees and use of concrete /plastic pond 


\section{Climate Change Effects}

Increase in Global Mean Temperature

- Increase in maximum temperature on hot days

- Increase in minimum temperature on cold days

- Increase in annual occurrence of hot day

- Increase in frequency, duration and intensity of heat waves

Gradual Changes in Precipitation

- Increase in frequency, duration and intensity of dry spells and droughts.

- Changes in timing, location and amounts of rain

Increase in Frequency and Intensity of Extreme Weather Events

- Increase in annual occurrence of high winds, heavy rains, storm surges and flash floods. Greater Weather Variability

- Greater instability in seasonal weather patterns

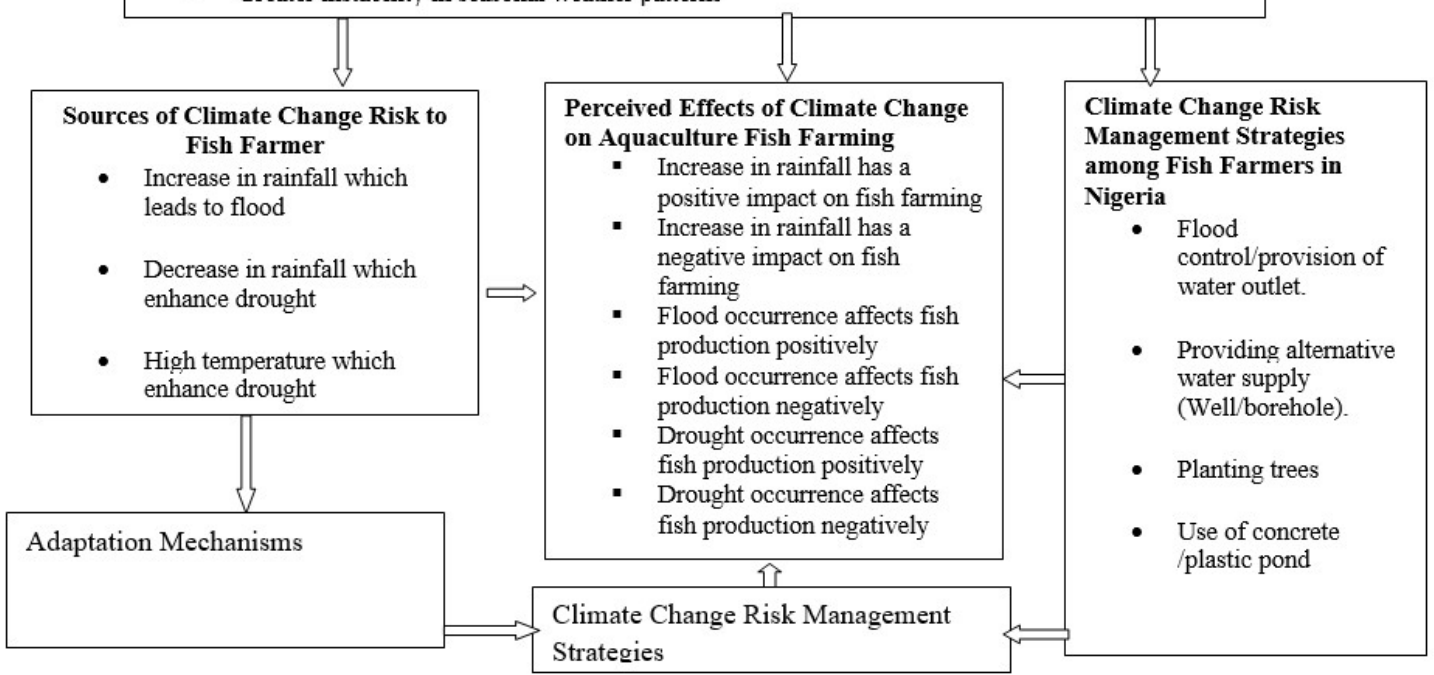

Figure 1: The Channels of Aquaculture Fish Farmer to Effect of Climate Change Risk

Source: own research and processing

\section{Materials and Methods Study Area}

The study was conducted in Ekiti, Ondo, Oyo and Osun States in the Southwest Nigeria. The four States are made up of 97 Local Government Areas (LGAs); Ekiti has 16 LGAs, Ondo 18 LGAs, Oyo 33 LGAs and Osun 30 LGAs (Adejuwon and Odekunle, 2014). The four States are in the southern guinea savannah of Nigeria which covers an area that has an average annual temperature and rainfall of $27.3^{\circ} \mathrm{C}$ and $1051.7 \mathrm{~mm}$ respectively. The false balsam Copaiba (Daniellia oliveri), used for carving mortars and pestles for pounding yam and Vitex, Khaya senegalensis (the poor mahogany) are the species found in the guinea savannah of Nigeria. The rainforest zone of Nigeria is characterized with a prolonged rainy season, resulting in average annual rainfall close to $1500 \mathrm{~mm}$, thereby ensuring an adequate supply of water and promoting perennial tree growth. Economic cash crops such as oil palm, (Elaeis guineensis), cocoa (Theobroma cacao), banana/plantain (Musa spp.) and cola nut (Cola nitida) are found in the rainforest zone of Nigeria. (Omotosho, 2012). The four States (i.e. Ekiti, Ondo, Oyo and Osun) have a high density of human population of 12,388,711 (National Bureau of Statistics (NBS), 2017) with agriculture as primary occupation of the people. Also found are some principal staple food crops such as yam, cocoyams, maize, rice, and cowpeas as well as a number of fruits. (Omonijo et al., 2014). The States are endowed with abundant natural resources ranging from huge mineral deposits, rich forest resources, great human and institutional resources.

\subsection{Sample and Sampling Techniques}

A multi-stage sampling technique was used for the study. Three States namely Ekiti, Ondo, Oyo and Osun were purposively selected for the study because the States accounted for the highest number of aquaculture fish production in the Southwest region of Nigeria (NBS, 2017). In each State, two Local Government Areas (LGAs) that accounted for the highest number of aquaculture fish farmers were purposively selected for the study. In each LGA, three (3) communities that accounted for the highest number of fish farmers were purposively selected through the assistance of the State Department of Fisheries (SDF) extension agents in each state. In each community, 20 fish farmers were randomly selected. Therefore, 180 fish farmers were interviewed for the study. 
Table 1: Summary of Sample Size

\begin{tabular}{lll}
\hline No & Sampled & Size \\
\hline 1 & State & 4 \\
2 & Local Government Area (LGA) & 2 from each State \\
3 & Communities & 3 from each LGA \\
4 & Fish farmers & 20 from each Communities \\
\hline \multicolumn{2}{c}{ Total (4x2x3x20) } & $\mathbf{4 8 0}$ \\
\hline & Source: own research and processing
\end{tabular}

\subsection{Nature and Sources of Data}

Primary data were used for this study; data were obtained through administering structured questionnaire on the fish farmers who were visited. The dataset collected from the farmers include: their awareness of climate change, the observable climate change phenomenon, the adaptation strategies commonly use to mitigate the perceived effects of climate change on their fish production.

\subsection{Data Analysis and Model Specification}

Descriptive statistics comprising of frequency distribution, mean, bar chart and percentages were used to describe the socio-economic characteristics of the aquaculture fish farmers', awareness of climate change, the climate variables observed and adaptation strategies practiced by fish farmers in the study area. A 5-points Likert-type scale was used to determine farmers' perception of effects of climate change on fish production in the study area. Fish farmers were asked to respond to statements listed in table 2. Using Strongly Agreed (SA), Agreed (A) Undecided (U), Disagreed (D), and Strongly Disagreed (SD), the responses were scored as 5,4,3,2 and1 for SA, A, $\mathrm{U}, \mathrm{D}$ and SD, respectively. The mean from each statement was obtained and used to classify the responses on each statement into SA (>4.50), A (3.50-4.49), U (2.50-3.49), D (1.50-2.49) and SD $(<1.50)$. The grand means for all the statements were calculated and used to place all the responses on a continuum that enabled a conclusion to be drawn on the perception of the aquaculture fish farmers' effects of climate change on fish production in the study area.

Table 2: Perceived Effects of Climate Change on Fish Farming in Study Area According to the

\section{Respondents}

$\mathrm{S} / \mathrm{N} \quad$ Perceived Effects of Climate Change on Aquaculture

1 Increase in rainfall has a positive impact on fish farming

2 Increase in rainfall has a negative impact on fish farming

$3 \quad$ Flood occurrence affects fish production positively

4 Flood occurrence affects fish production negatively

5 Drought occurrence affects fish production positively

6 Drought occurrence affects fish production negatively

\section{Source: own research and processing}

The Multinomial Logit Model was used to analyze the factors that influences the number of risk management strategies used by the aquaculture fish farmers' in the study area.

Multinomial Logit Model (MNL) is stated thus:

$$
\begin{aligned}
& \operatorname{Pr}\left(\mathrm{Y}_{\mathrm{i}}=\mathrm{j}\right)=\alpha \beta_{\mathrm{j}} \mathrm{x}_{\mathrm{j}} \mathrm{j}, \mathrm{j}=0,1,2 \text {, --------------- } 4 \text {--------------------- (1) }
\end{aligned}
$$

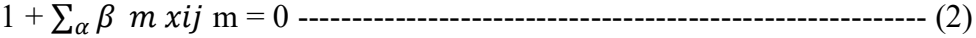

$$
\begin{aligned}
& \operatorname{Pj}=\operatorname{Pr}\left(Y_{i}=j\right)=\alpha \beta_{j} x_{i} j, j=0,1,2,-----------4
\end{aligned}
$$

Where:

$\mathrm{J}_{\mathrm{i}}=$ number of climate change risk management strategies option in the choice set

$\mathrm{X}_{\mathrm{i}}=$ vector of the predictor (exogenous) socioeconomic factors (variables) such as age and level of education among others.

$\beta_{\mathrm{j}}=$ vector of the estimated parameters

The model specification is given explicitly and stated thus:

$$
\begin{aligned}
& \left(\mathrm{P}_{\mathrm{i}} / 1-\mathrm{P}_{\mathrm{i}}\right)=\mathrm{Y}_{\mathrm{i}}=\beta_{0}+\beta_{1} \mathrm{X}_{1}+\beta_{2} \mathrm{X}_{2}+\beta_{3} \mathrm{X}_{3}+\beta_{4} \mathrm{X}_{4}+ \\
& \beta_{12} \mathrm{X}_{12}+\mathrm{U}_{\mathrm{i}}
\end{aligned}
$$

$1=$ Flood control/provision of water outlet

$2=$ Providing alternative water supply (Well/borehole)

$3=$ Planting trees

$4=$ Use of concrete /plastic pond

$\mathrm{U}_{\mathrm{i}}=$ Error term

In line with Al-Assaf et al., (2013) to interpret the coefficients, the marginal effect for each coefficient was estimated, where the coefficients themselves represent probabilities. The marginal effect can be expressed as: 
$\mathrm{dy} / \mathrm{dx}=\alpha \beta_{\mathrm{j}} \mathrm{x}_{\mathrm{j}} \mathrm{j}$

Using this model makes the results easier to interpret and the statistic tests are immediately available. The effect of the explanatory variables can be captured simultaneously.

$\beta_{0}=$ Intercept or constant

$\beta_{1}=$ Vector of parameter estimates

$\mathrm{X}_{1}=$ Age

$\mathrm{X}_{2}=$ Gender

$\mathrm{X}_{3}=$ Education Attained

$\mathrm{X}_{4}=$ Farm Income

$\mathrm{X}_{5}=$ Fish Farming Experience

$\mathrm{X}_{6}=$ Access to Credit

$\mathrm{X}_{7}=$ Size of Pond

$\mathrm{X}_{8}=$ Type of Pond

$\mathrm{X}_{9}=$ Source of Water

$\mathrm{X}_{10}=$ Marital Status

$\mathrm{X}_{11}=$ Solely Fish Farming Business

$\mathrm{X}_{12}=$ Access to Extension Agent

\section{Results and discussion}

From the result as shown in the Table 3, the gender variation of the respondents as observed on the field shows that $84 \%$ of the respondents were males, which shows that fish farming is male dominated agribusiness in the study area. This may be due to the labourious nature and time required for sustaining a fish farm enterprise (Thompson, 2017). The results further revealed that $81 \%$ of the respondents were within the working productive age (i.e. 18 years to 60 years) and this was buttressed by the mean age of about 50years. The study further reveals that the mean farming experience of the respondents is 7.79 years with 6-10 years having a modal distribution of $277(57.7 \%)$. This implies that fish farming is not a new agribusiness in the study area. Experience gained on farm first-hand is better than theory read in schools or from seminars and workshops (Gelles \& Mitchell, 2006). The marital status of respondents reveals that $82.7 \%$ of the respondents were married; most of the fish farmers may likely rely on family labour to augment hired labour thereby reducing the cost of labour in the study area (Amujoyegbe \& Alabi, 2012). Also, as shown in Table 3, 62.3\% of the respondents were solely into fish farming, such may be vulnerable to climate change risk since they depend solely on income from the fish farm (FAO, 2013). While the remaining $37.7 \%$ may be less vulnerable to climate change risk because they are civil servants and can fall back on their salary for livelihood sustenance in case of risk because of climate change. The study reveals in Table 3 that the level of education of the fish farmers was high, tertiary educational level had a modal frequency distribution of 277 representing 57.7\%. According to Olarinde \& Kuponiyi, (2014) "Education is an important factor that determines adoption of new innovations. It provides readability, consciousness and awareness, which enhance better decisions to be made. Therefore, the higher the level of farmer's education, the better his decisionmaking ability, especially in the adoption of new technologies and innovation" (Kariuki \& Mwangi, 2015).

Frequency distribution of ponds sizes in the sampled area shows that $57.3 \%$ of the ponds were small sized ponds of between $100 \mathrm{~m}^{2}$ and $250 \mathrm{~m}^{2}$. The highest percentage of the small pond of between $100 \mathrm{~m}^{2}$ and $250 \mathrm{~m}^{2}$ as shown in Table 3 may be due to lack of skills and infrastructural facilities to accommodate large scale fish farming as well as limited data and information on research and development requirements for large scale fish farming. Also, it was observed from the survey that about $22.3 \%$ of the farms sampled made use of earthen pond and $77.7 \%$ made use of concrete /plastic pond. This may be since concrete /plastic ponds are more secure and reliable than the earthen ponds (Adebayo, 2012). Table 3 again revealed that $77.7 \%$ of the surveyed fish farmers had their water sources from wells and borehole, $22.3 \%$ of them had their water sources from a combination of rivers, streams, irrigational canals and collected run - offs. Water supply from boreholes and wells tend to be more dependable, consistent and such water is usually free from disease organism, parasites, and predators, although it is expensive to construct boreholes. However, surface water sources such as streams, irrigational canals and collected run - offs on the other hand often fluctuate in quality and quantity (Adeleke \& Balogun, 2013). 
Table 3: Socio-Economic Characteristics of Fish Farmers in the Study Area

\begin{tabular}{|c|c|c|}
\hline \multirow[t]{2}{*}{ Socio-economic Characteristics } & \multicolumn{2}{|c|}{ (2) } \\
\hline & Frequency & Percentage \\
\hline Gender & & \\
\hline Male & 403 & 84.0 \\
\hline Female & 77 & 16.0 \\
\hline Total & 480 & 100 \\
\hline Age in years & & \\
\hline $30-39$ & 117 & 24.4 \\
\hline $40-49$ & 179 & 37.2 \\
\hline $50-59$ & 93 & 19.4 \\
\hline$>60$ & 91 & 19.0 \\
\hline Total & 480 & 100 \\
\hline Fish Farming Experience in years & & \\
\hline $1-10$ & 277 & 57.7 \\
\hline $11-20$ & 149 & 31.0 \\
\hline $21-30$ & 54 & 11.3 \\
\hline Total & 480 & 100 \\
\hline Marital Status & & \\
\hline Single & 8 & 1.7 \\
\hline Married & 397 & 82.7 \\
\hline Divorced & 0 & 0 \\
\hline Widowed & 75 & 15.6 \\
\hline Total & 480 & 100 \\
\hline Solely Fish Farming Business & & \\
\hline Self-employed. & 299 & 62.3 \\
\hline Civil Servant & 181 & 37.7 \\
\hline Total & 480 & 100 \\
\hline Education Attained & & \\
\hline Completed Secondary School & 203 & 42.3 \\
\hline Completed Tertiary & 277 & 57.7 \\
\hline Total & 480 & 100 \\
\hline Size of Pond & & \\
\hline $100-250 \mathrm{~m}^{2}$ & 275 & 57.3 \\
\hline $251-999 \mathrm{~m}^{2}$ & 187 & 39.0 \\
\hline Above $1000 \mathrm{~m}^{2}$ & 18 & 3.7 \\
\hline Total & 480 & 100 \\
\hline Type of Ponds & & \\
\hline Concrete/Plastic Pond & 373 & 77.7 \\
\hline Earthen Pond & 107 & 22.3 \\
\hline Total & 180 & 100 \\
\hline Source of Water & & \\
\hline Well/Borehole. & 373 & 77.7 \\
\hline Stream/river/ irrigational canals & 107 & 22.3 \\
\hline Total & 480 & 100 \\
\hline Mean Age of Fish Farmers & 49.89years & \\
\hline Mean Farming Experience & 7.79years & \\
\hline
\end{tabular}

Source: own research and processing

Again, as shown in figure 3,15\% of the respondents' income from fish farming was less than 100,000 Naira (\$274) per annum and 39\% have an income between 501,000 Naira and 1,000,000 Naira (\$1,372.60 and \$2740) per annum. 30\% said they have above 1,000,000 Naira (\$2740) per annum as income from fish farming. Therefore, with an average income of 1,057,500 Naira (\$2897.26) per annum, fish farming is profitable in the study area. This support the findings of Food and Agricultural Organization (FAO, 2013) that fish farming is profitable in Nigeria. 


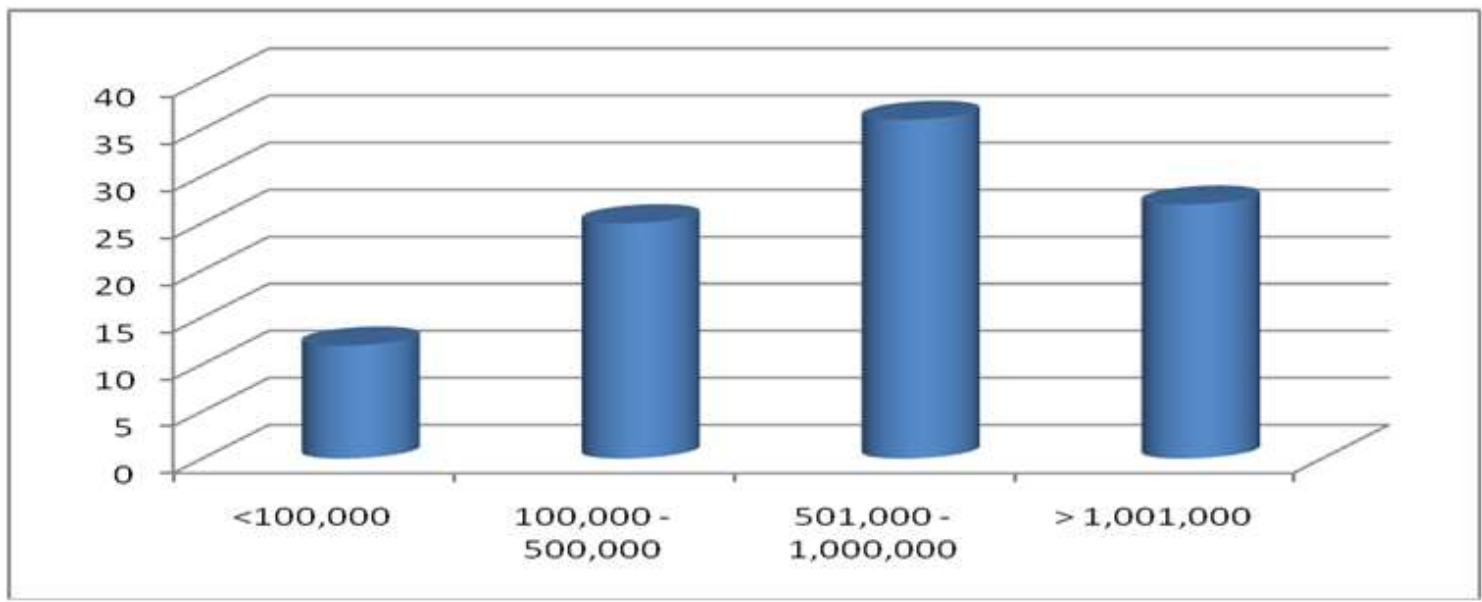

Figure 3: Fish Farm Income

Source: own research and processing

Earthen pond depends on stream, river and irrigational canals water and it's susceptible to climate change effects such as flood and drought. According to the respondents, earthen pond used to be their normal fish farming practice without taking into cognizance the concept of climate change. Earthen pond solely depends on rainfall which is one of the climatic variables. Fluctuation in rainfall is one of the key features of climate change that serves a source of risk to aquaculture fish farmers' that depend on earthen pond. Frequent rainfall leads to flooding which washes the fish away and when the frequency of rainfall is low, it leads to drought. Hence, fish farming becomes difficult because expected natural water from the stream, river and irrigation canal will not be available according to the respondents. Plastic/concrete ponds depends on wells and boreholes. Is more secure and under control environment. The pond is less prone to climate change risk because it was designed to mitigate the effect of climate change in the study area. According to the fish farmers' in the study area, since they perceived climate change via fluctuation in rainfall which often affects the availability of water for their fish farming, they have to design the plastic and concrete pond. The plastic and concrete ponds do not depend on rainfall but on borehole, hence it mitigates the effect of climate change on their fish farming in the study area. It safe them from loosing the fishes during rain flood and help mitigate against drought.

Likert scale result in Table 4 revealed that the respondents agreed that increase in rainfall has a positive impact on fish farming (4.18). According to the respondents, increase in rainfall enhances availability of water for fish production in the study area. This is in line with the finding of Adeleke and Omoboyeje, (2016) that fish farming is rampant during raining season in the Southwest Nigeria. The respondents disagree (2.48) that increases in rainfall have a negative impact on fish farming. They disagree (2.46) that flood occurrence affects fish production positively, they explained that flood usually washes away some of their fish and agreed that it affects fish production negatively (4.03). This buttress the findings of Thompson, (2017) that climate change through unprecedented increase in rainfall that leads to flooding affects the fisheries sub-sector of Nigeria. The respondents as shown in the Table were undecided about the positive (2.81) and negative (2.96) effects of drought on fish farming in the study area. As shown in Table 3,77.7\% of the respondents were using concrete/plastic pond and about $77.7 \%$ of the respondents were making use of well and borehole in the study area. There is likelihood that they may be indifferent to the effects of drought on fish farming since they do not depend on rainfall. This is in conformity with the findings of (Ayanwuyi et al., 2012) that when fish farmers don't depend on streams, rivers and irrigational canals which are natural sources of water for fish farming, they are less prone to climate change risk as a result of flood and drought. 
Table 4: Fish Farmers' Perception of Effects of Climate Change Risk in the Study Area

\begin{tabular}{|c|c|c|c|c|c|c|c|c|}
\hline \multirow[t]{2}{*}{$\mathbf{S} / \mathbf{N}$} & \multirow[t]{2}{*}{ Perception Statements } & \multicolumn{7}{|c|}{ Responses } \\
\hline & & $\mathbf{S A}$ & $\mathbf{A}$ & $\mathbf{U}$ & D & SD & $\begin{array}{l}\text { Mean Score } \\
X\end{array}$ & Remark \\
\hline 1 & $\begin{array}{l}\text { Increase in rainfall has a positive } \\
\text { impact on fish farming }\end{array}$ & $\begin{array}{l}189 \\
(39.4)\end{array}$ & $\begin{array}{l}165 \\
(34.4)\end{array}$ & $\begin{array}{l}0 \\
(0)\end{array}$ & $\begin{array}{l}72 \\
(15.0)\end{array}$ & $\begin{array}{l}54 \\
(11.2)\end{array}$ & 4.18 & $\mathbf{A}$ \\
\hline 2 & $\begin{array}{l}\text { Increase in rainfall have a } \\
\text { negative impact on fish farming }\end{array}$ & $\begin{array}{l}96 \\
(20.0)\end{array}$ & $\begin{array}{l}69 \\
(14.4)\end{array}$ & $\begin{array}{l}32 \\
(6.7)\end{array}$ & $\begin{array}{l}155 \\
(32.3)\end{array}$ & $\begin{array}{l}128 \\
(26.7)\end{array}$ & 2.48 & $\mathrm{D}$ \\
\hline 3 & $\begin{array}{l}\text { Flood occurrence affects fish } \\
\text { production positively }\end{array}$ & $\begin{array}{l}53 \\
(11.0)\end{array}$ & $\begin{array}{l}107 \\
(22.3)\end{array}$ & $\begin{array}{l}51 \\
(10.6)\end{array}$ & $\begin{array}{l}147 \\
(30.6)\end{array}$ & $\begin{array}{l}122 \\
(25.5)\end{array}$ & 2.46 & D \\
\hline 4 & $\begin{array}{l}\text { Flood occurrence affects fish } \\
\text { production negatively }\end{array}$ & $\begin{array}{l}141 \\
(29.4)\end{array}$ & $\begin{array}{l}157 \\
(32.7)\end{array}$ & $\begin{array}{l}93 \\
(19.4)\end{array}$ & $\begin{array}{l}67 \\
(14.0)\end{array}$ & $\begin{array}{l}22 \\
(4.5)\end{array}$ & 4.03 & $\mathbf{A}$ \\
\hline 5 & $\begin{array}{l}\text { Drought occurrence affects fish } \\
\text { production positively }\end{array}$ & $\begin{array}{l}27 \\
(5.6)\end{array}$ & $\begin{array}{l}88 \\
(18.3)\end{array}$ & $\begin{array}{l}240 \\
(50.0)\end{array}$ & $\begin{array}{l}107 \\
(22.2)\end{array}$ & $\begin{array}{l}18 \\
(3.9)\end{array}$ & 2.81 & $\mathbf{U}$ \\
\hline 6 & $\begin{array}{l}\text { Drought occurrence affects fish } \\
\text { production negatively. }\end{array}$ & $\begin{array}{l}53 \\
(11.0)\end{array}$ & $\begin{array}{l}61 \\
(12.7)\end{array}$ & $\begin{array}{l}211 \\
(44.0)\end{array}$ & $\begin{array}{l}101 \\
(21.0)\end{array}$ & $\begin{array}{l}54 \\
(11.3)\end{array}$ & 2.96 & $\mathbf{U}$ \\
\hline
\end{tabular}

Source: own research and processing

All the respondents $(100 \%)$ in the study area were aware of climate change. Hence, they tried to mitigate its effects on their fish production. According to Amujoyegbe \& Alabi, (2012) most of the fish farmers in the Southwest Nigeria are aware of effects of climate change and are familiar with several adaptation strategies. The commonly used adaptation strategy by the fish farmers in the study area was use of concrete/plastic pond (78\%) as shown in figure 8 . These two artificial ponds are reliable, saver and cheaper means of adapting to climate change (Adeleke and Balogun, 2013). The least (2\%) used adaptation strategy in the study area was flood control/provision of water outlets. This is very expensive for them and may be unreliable if the flood become unprecedented during heavy and incessant rainfall.

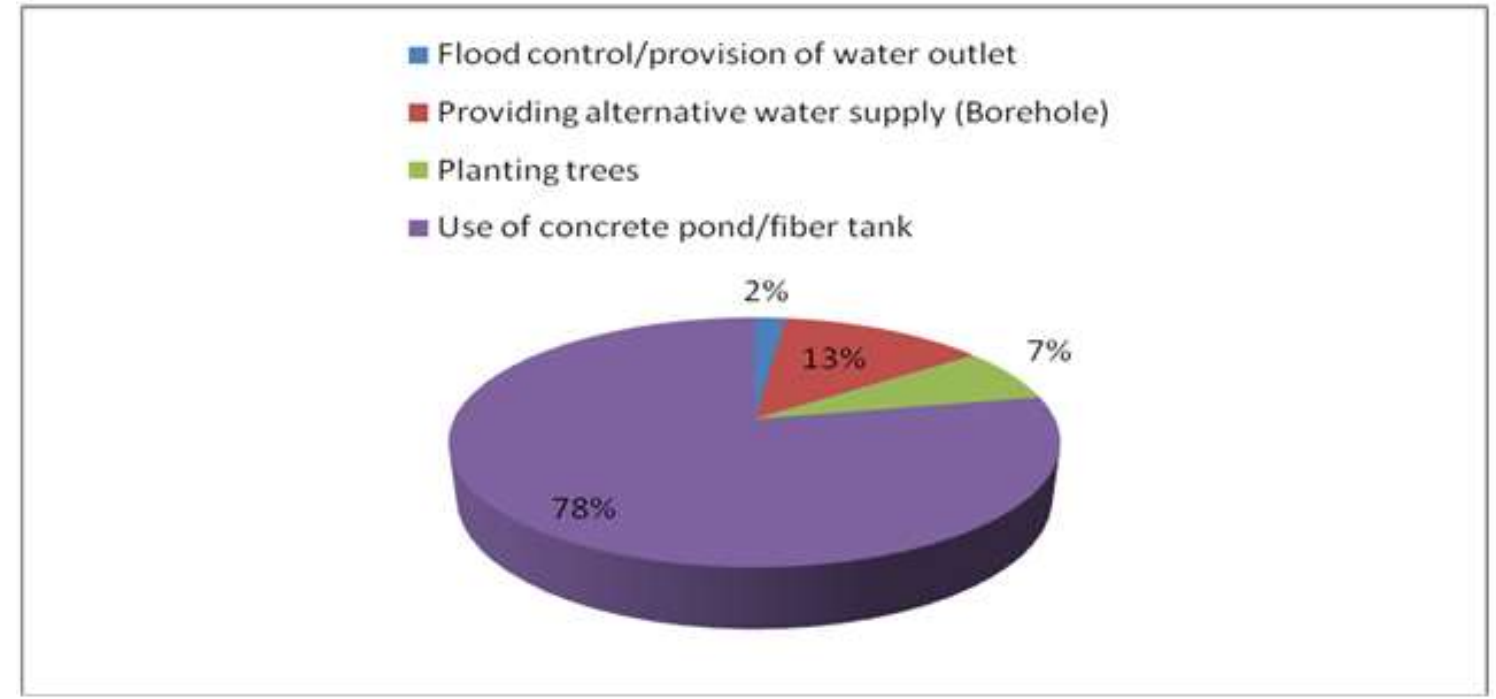

Figure 4: Commonly Used Adaptation Strategy by the Fish Farmers in the Study Area.

Source: own research and processing

Table 5 shows that $72.3 \%$ of the respondents observed unpredictable rainfall, $55.6 \%$ observed an increase in temperature, $66.7 \%$ observed incessant flood, $58.3 \%$ drought as most observable climate change phenomenon in the study area. This result conforms to the findings of Adeleke and Omoboyeje, (2016) that unpredictable rainfall is the most observable climate change phenomenon in the Southwest Nigeria.

Table 5: Distribution of Fish Farmers Observable Climate Change Phenomenon

\begin{tabular}{lll}
\hline Climate Change Phenomenon & Frequency & Percentage \\
\hline Unpredictable rainfall & 347 & 72.3 \\
Increased Temperature & 267 & 55.6 \\
Incessant flood & 320 & 66.7 \\
Drought & 280 & 58.3 \\
\hline \multicolumn{2}{c}{ *Multiple responses recorded. } \\
& Source: own research and processing
\end{tabular}


As shown in Table 6, regarding the model fitting information, the $X^{2}$ ratio tests had a value of $288.675(P-$ value < 0.000) (AIC criterion 1388; Hannan-Quinn criterion: 1463), indicating good model fit. In addition, acceptable values were obtained from pseudo $r^{2}$ (Cox and Snell: 0.512; Nagelkerke: 0.431 ). The reference category for the model was use of concrete and plastic pond, as it is the most common adaptation strategy in the study area. Furthermore, the Table revealed that age significantly affects the provision of alternative water supply (Borehole) in the study area. The coefficient was negatively significant at $1 \%$ level of significant and with -0.032 marginal effect. This implying that increase in the age of the respondents will likely reduce the use of alternative water supply which is borehole relative to the use of concrete and plastic pond. This is in conformity with the finding of Mayo, (2016) that as farmers are growing in age, they may not be willing to invest more on the farm, because they will not be willing to take risk again.

As shown in the Table, farm income was positively significant at $1 \%$ level of significant to the use of flood control/provision of water outlet and provision of alternative water supply (Borehole) with marginal effect of 9.5368 and 0.31 respectively. While it was positively significant at $5 \%$ level of significant to the use of concrete /plastic pond with marginal effect of 0.07 . The results implies that increase in the income from the aquaculture business will probably increase the adoption of flood control/provision of water outlet, provision of alternative water supply (Borehole) and the use of concrete /plastic pond as climate change risk management strategies among the aquaculture fish farmers in the study area. This is in conformity with the findings of (Ayanwuyi et al., 2012) that the income from fish farm determines the farmer investment on the farm. Flood control/provision of water outlet, providing alternative water supply (Well/Borehole), use of concrete /plastic pond are all investment that were positively significant. Therefore, increase in farm income will lead to increase in these adaptation strategies (i.e. Flood control/provision of water outlet, providing alternative water supply (Well/Borehole), use of concrete /plastic pond) to mitigate the effects of climate change on fish production in the study area.

From the Table, access to credit and size of pond were significantly positive at $5 \%$ level of significant to determine the provision of alternative water supply (Well/Borehole) as means of climate change risks management strategies in the study area. These variables (i.e. Access to credit and size of pond) has marginal effect of 0.5062 and 0.7563 respectively, this implies that increase in access to credit and size of pond will probably enhance the fish farmers in the study area to consider the use of provision of alternative water supply (Well/Borehole) as means of climate change risks management strategies. Thompson and Amos, (2017) confirm this, that fish farmers' access to credit will assist them to mitigate the effects of climate change in Nigeria and the bigger the size of fish pond, the more willing the fish farmers will be willing to provide alternative water supply (Well/Borehole) to guide against his/her investment in the fish farming enterprise. Fish farmers experience was equally positively significant at $10 \%$ level of significant to the use of flood control/provision water outlet as a means of climate change risks management strategies in the study area with marginal effect of 0.1584 . This shows that the more experience a fish farmer is, the higher the probability of him using the flood control/provision water outlet as a means of climate change risks management strategies in the study area. This support the findings of Perroni, (2017) that an experience fish farmer will be willing to protect his fish farm against any effect of flooding and drought.

\subsection{Conclusion}

The study assessed the fish farmers awareness of climate change, determine the most observable climate change phenomenon and the adaptation strategies commonly use to mitigate the perceived effects of climate change on their fish production in the study area. Again, fish farmers' perception of effects of climate change on fish production in the study area was determined in the study. The profitability of aquaculture fish production was determined in the study. The factors that influences the number of risk management strategies used by the aquaculture fish farmers' in the study area was determined in the study. The study revealed that all the respondents in the study area were aware of climate change. Hence, they tried to mitigate its effects on their fish production. The commonly used adaptation strategy by the fish farmers in the study area was use of concrete/plastic pond. Age significantly affects the provision of alternative water supply (Borehole) in the study area as revealed in the study. Farm income positively influence the use of flood control/provision of water outlet and provision of alternative. Access to credit and size of pond were positively determine the provision of alternative water supply (Well/Borehole) as means of climate change risks management strategies in the study area. Farming experience was positively determined the use of flood control/provision water outlet as a means of climate change risks management strategies in the study area.

Therefore, from the study, the following policy implications can be deduced, government and NonGovernmental Organizations (NGOs) should take into consideration the age of the fish farmers in any intervention programmes. Since the aged fish farmers will not be willing to take risk, then such intervention should consider the young fish farmers. Efforts should be made to boost the income of fish farmers to enhance their mitigation effort against the effect of climate change in the study area. Credit facilities should be made available to the fish farmers in the study area, because this will empower them to efficiently manage climate change risk as appropriate. Likewise, policy makers at all levels should take into consideration the farming experience of the fish farmers in 
planning any environmental related intervention for the aquaculture fish farmers in the study area.

Table 6: Estimated Multinomial Logit Analysis of the Factors Influencing Risk Management Strategies Adopted by Fish Farmers in the Study Area

\begin{tabular}{|c|c|c|c|c|c|c|c|c|}
\hline \multirow[t]{2}{*}{$\begin{array}{l}\text { Explanatory } \\
\text { Variables }\end{array}$} & \multicolumn{2}{|c|}{$\begin{array}{l}\text { Flood control/provision } \\
\text { of water outlet }\end{array}$} & \multicolumn{2}{|c|}{$\begin{array}{l}\text { Providing alternative } \\
\text { water supply (Borehole) }\end{array}$} & \multicolumn{2}{|c|}{ Planting trees } & \multicolumn{2}{|c|}{ Use of concrete /plastic pond } \\
\hline & Coeff. & $\begin{array}{l}\text { Marginal } \\
\text { Effect }\end{array}$ & Coeff. & $\begin{array}{l}\text { Marginal } \\
\text { Effect }\end{array}$ & Coeff. & $\begin{array}{l}\text { Marginal } \\
\text { Effect }\end{array}$ & Coeff. & $\begin{array}{l}\text { Marginal } \\
\text { Effect }\end{array}$ \\
\hline Age $\left(X_{1}\right)$ & $\begin{array}{l}0.03929 \\
(0.03809)\end{array}$ & $\begin{array}{l}0.4984 \\
(1.1416)\end{array}$ & $\begin{array}{l}-0.5613 * * * \\
(0.3093)\end{array}$ & $\begin{array}{l}-0.032 * * * \\
(0.017)\end{array}$ & $\begin{array}{l}1.1476 \\
(1.4800)\end{array}$ & $\begin{array}{l}0.3727 \\
(0.7812)\end{array}$ & $\begin{array}{l}0.5526 \\
(1.5495)\end{array}$ & $\begin{array}{l}0.5262 \\
(2.5062)\end{array}$ \\
\hline $\operatorname{GEN}\left(\mathbf{X}_{2}\right)$ & $\begin{array}{l}0.9374 \\
(1.3049)\end{array}$ & $\begin{array}{l}0.2714 \\
(1.2929)\end{array}$ & $\begin{array}{l}0.0500 \\
(1.4568)\end{array}$ & $\begin{array}{l}0.2274 \\
(0.4759)\end{array}$ & $\begin{array}{l}0.4115 \\
(1.0007)\end{array}$ & $\begin{array}{l}0.1870 \\
(1.9247)\end{array}$ & $\begin{array}{l}0.5589 \\
(1.4695)\end{array}$ & $\begin{array}{l}0.4864 \\
(1.6160)\end{array}$ \\
\hline $\operatorname{EDU}\left(\mathbf{X}_{3}\right)$ & $\begin{array}{l}0.1732 \\
(1.1797)\end{array}$ & $\begin{array}{l}0.0122 \\
(0.0671)\end{array}$ & $\begin{array}{l}1.4008 \\
(2.2411)\end{array}$ & $\begin{array}{l}0.0871 \\
(0.1367)\end{array}$ & $\begin{array}{l}0.2322 \\
(1.6732)\end{array}$ & $\begin{array}{l}2.8960 \\
(10.9131)\end{array}$ & $\begin{array}{l}0.1352 \\
(0.3932)\end{array}$ & $\begin{array}{l}0.2784 \\
(2.7942)\end{array}$ \\
\hline FIN $\left(X_{4}\right)$ & $\begin{array}{l}1.3837 * \\
(0.4418)\end{array}$ & $\begin{array}{l}9.5368 * \\
(3.0532)\end{array}$ & $\begin{array}{l}6.6438^{*} \\
(2.2919)\end{array}$ & $\begin{array}{l}0.31 * \\
(0.11)\end{array}$ & $\begin{array}{l}3.0745 \\
(4.1345)\end{array}$ & $\begin{array}{l}0.1172 \\
(0.1518)\end{array}$ & $\begin{array}{l}1.6875 * * \\
(0.7291)\end{array}$ & $\begin{array}{l}0.07 * * \\
(0.03)\end{array}$ \\
\hline FFE $\left(X_{5}\right)$ & $\begin{array}{l}3.2236 \text { *** } \\
(1.6855)\end{array}$ & $\begin{array}{l}0.1584 * * * \\
(0.0846)\end{array}$ & $\begin{array}{l}8.0935 \\
(8.5654)\end{array}$ & $\begin{array}{l}0.5361 \\
(0.4879)\end{array}$ & $\begin{array}{l}1.1540 \\
(2.7931)\end{array}$ & $\begin{array}{l}0.0218 \\
(0.0504)\end{array}$ & $\begin{array}{l}1.6960 \\
(2.3524)\end{array}$ & $\begin{array}{l}0.0306 \\
(0.0426)\end{array}$ \\
\hline $\operatorname{ACC}\left(X_{6}\right)$ & $\begin{array}{l}1.0782 \\
(5.1984)\end{array}$ & $\begin{array}{l}0.0338 \\
(0.1542)\end{array}$ & $\begin{array}{l}5.4588^{* *} \\
(2.1992)\end{array}$ & $\begin{array}{l}0.5062 * * \\
(0.2177)\end{array}$ & $\begin{array}{l}0.7172 \\
(2.8870)\end{array}$ & $\begin{array}{l}2.4105 \\
(1.9338)\end{array}$ & $\begin{array}{l}2.9037 \\
(2.2624)\end{array}$ & $\begin{array}{l}4.0750 \\
(2.6750)\end{array}$ \\
\hline $\operatorname{SPN}\left(X_{7}\right)$ & $\begin{array}{l}0.0466 \\
(0.0389)\end{array}$ & $\begin{array}{l}0.0135 \\
(0.0394)\end{array}$ & $\begin{array}{l}12.0036^{* *} \\
(4.8361)\end{array}$ & $\begin{array}{l}0.7563 * * \\
(0.3253)\end{array}$ & $\begin{array}{l}0.4649 \\
(1.0649)\end{array}$ & $\begin{array}{l}0.1969 \\
(1.9736)\end{array}$ & $\begin{array}{l}0.6831 \\
(1.4908)\end{array}$ & $\begin{array}{l}1.2955 \\
(1.8034)\end{array}$ \\
\hline TPN $\left(\mathbf{X}_{8}\right)$ & $\begin{array}{l}1.1316 \\
(4.8521)\end{array}$ & $\begin{array}{l}2.8407 \\
(3.2190)\end{array}$ & $\begin{array}{l}0.6872 \\
(1.9269)\end{array}$ & $\begin{array}{l}0.3886 \\
(1.8511)\end{array}$ & $\begin{array}{l}0.1779 \\
(2.6279)\end{array}$ & $\begin{array}{l}0.5456 \\
(2.3206)\end{array}$ & $\begin{array}{l}2.8853 \\
(2.3618)\end{array}$ & $\begin{array}{l}0.7088 \\
(2.2750)\end{array}$ \\
\hline SOW $\left(X_{9}\right)$ & $\begin{array}{l}1.1982 \\
(2.5091)\end{array}$ & $\begin{array}{l}0.2618 \\
(2.6945)\end{array}$ & $\begin{array}{l}0.9655 \\
(2.5382)\end{array}$ & $\begin{array}{l}0.08 \\
(2.3309)\end{array}$ & $\begin{array}{l}0.9727 \\
(2.3655)\end{array}$ & $\begin{array}{l}0.7164 \\
(2.38)\end{array}$ & $\begin{array}{l}0.2635 \\
(0.4736)\end{array}$ & $\begin{array}{l}0.0173 \\
(0.0264)\end{array}$ \\
\hline $\operatorname{MAR}\left(X_{10}\right)$ & $\begin{array}{l}0.4701 \\
(0.5117)\end{array}$ & $\begin{array}{l}0.0294 \\
(0.284)\end{array}$ & $\begin{array}{l}0.3970 \\
(0.4980)\end{array}$ & $\begin{array}{l}0.0223 \\
(0.0279)\end{array}$ & $\begin{array}{l}0.0208 \\
(0.0604)\end{array}$ & $\begin{array}{l}0.4269 \\
0.5604)\end{array}$ & $\begin{array}{l}0.0173 \\
(0.0228)\end{array}$ & $\begin{array}{l}0.2107 \\
(0.6400)\end{array}$ \\
\hline $\operatorname{SFFB}\left(X_{11}\right)$ & $\begin{array}{l}0.007 \\
(0.0208)\end{array}$ & $\begin{array}{l}0.5299 \\
(0.6137)\end{array}$ & $\begin{array}{l}0.0223 \\
(0.0249)\end{array}$ & $\begin{array}{l}0.4320 \\
(0.5847)\end{array}$ & $\begin{array}{l}0.0173 \\
(0.0234)\end{array}$ & $\begin{array}{l}0.0112 \\
(0.6558)\end{array}$ & $\begin{array}{l}1.4949 \\
(1.4218)\end{array}$ & $\begin{array}{l}0.0010 \\
(0.0213)\end{array}$ \\
\hline EGA $\left(X_{12}\right)$ & $\begin{array}{l}0.0492 \\
(0.0472)\end{array}$ & $\begin{array}{l}0.4437 \\
(0.6416)\end{array}$ & $\begin{array}{l}0.0127 \\
(0.0183)\end{array}$ & $\begin{array}{l}6.4274 \\
(6.2664) \\
\end{array}$ & $\begin{array}{l}0.1279 \\
(0.1249)\end{array}$ & $\begin{array}{l}0.0949 \\
(0.8046)\end{array}$ & $\begin{array}{l}0.0015 \\
(0.0152)\end{array}$ & $\begin{array}{l}0.4883 \\
(0.7553) \\
\end{array}$ \\
\hline Intercept & $\begin{array}{l}2,4010 \\
(1.1553)\end{array}$ & & $\begin{array}{l}2.2503 \\
(1.1817)\end{array}$ & & $\begin{array}{l}1.6274 \\
(1.3056)\end{array}$ & & $\begin{array}{l}1.6066 \\
(1.2518)\end{array}$ & \\
\hline$X^{2}$ ratio test & & & & 288.675 & & & & \\
\hline Pseudo R-Sq & Cox and & ; Nagelke & McFadden) & $0.512 ; 0.4$ & 0,312 & & & \\
\hline
\end{tabular}

\section{References}

Abrahmse, W (2019). Encouraging Pro-Environmental Behaviour. What Works, What Doesn't, and Why. Elsevier Academic Press, London, United Kingdom, pp 49-65. ISBN: 9780128113608

Adebayo, O. O. (2012). Climate Change Perception and Adaptation Strategies on Catfish Farming in Oyo State, Nigeria. Global Journal of Science Frontier Research Agriculture and Veterinary Sciences, Vol. 2, No. 6, pp. 13-19.

Adejuwon, J. O. \& Odekunle, T. O. (2014). Variability and Severity of Little Dry Season in South Western Nigeria. Journal of Climate, Vol. 5, pp. 483-493.

Adeleke, M. L. \& Balogun A. A. (2013): Occurrence of Climate Change and Its Effects on the Fishing Activities in the Coastal Region of Ondo State, Nigeria. International Journal of Development and Economic Sustainability, Vol.1, No. 1, pp. 1-13.

Adeleke, M. L. \& Omoboyeje, V.O, (2016). Effects of Climate Change on Aquaculture Production and Management in Akure Metropolis, Ondo State, Nigeria. Nigerian Journal of Fisheries and Aquaculture, Department of Fisheries, Faculty of Agriculture, University of Maiduguri, Nigeria, Vol. 4, No.1, pp. 50 - 58.

Al-Assaf, G., Al-Tarawneh, A. \& Alawin, M. (2013). Determinants of Currency Crisis in Jordan A Multinomial

Logit Model. European Scientific Journal, ESJ. Vol.9, No. 34, pp. 354-369. ISSN: 1857 - 788. https://doi.org/10.19044/esj.2013.v9n34p\%p

Amujoyegbe1, B. J. \& Alabi, O. S. (2012). Cropping System Analysis of Two Agro Ecological Zones of Southwest Nigeria. Journal of Agricultural Extension and Rural Development, Vol. 4, No. 14, pp. 396-401

Ayanwuyi, E., Kuponiyi, F., Ogunlade, A. \& Oyetoro, J. O. (2012): Farmers Perception of Impact of Climate Changes on Food Crop Production in Ogbomosho Agricultural Zone of Oyo State, Nigeria. Global Journal of Human Social Science, Vol. 10, No. 7, pp. 33-41

Boholm, A. (1998) Comparative studies of risk perception: a review of twenty years of research. Journal of Risk Research, Vol. 1, pp. 135-163.

Coon, D. \& Mitterer, J.O. (2013). Introduction to Psychology: Gateways to Mind and Behavior, 13th ed.; 
Wadsworth, Cengage Learning: Belmont, UK.

Dake, K. \& Wildavsky, A (1990). Theories of risk perception: who fears what and why? Daedalus, Vol. 119, pp. 4159. (Google Scholar)

Dechassa, C., Simane, B., \& Alamerew, B. (2020). Analysis of farmers perceived and observed climate variability and change in Didessa sub-basin, Blue Nile River, Ethiopia. African Journal of Agricultural Research. Vol. 15, No.2, pp. 149-164. https://doi.org/10.5897/AJAR2019.14054

DFID (2014). The Effects of Climate change on World Aquaculture: A global perspective. Department for International Development, London

Fagbenro. O. A., Akinbulumo, M. O. \& Ojo, S. O. (2014): Tilapia: Fish for Aquaculture in Nigeria-Past Experience, Present Situation and Future Outlook (History, Status and Prospects). World Aquaculture. Vol. 35, No. 20, pp. 23-28.

FAO. (2013). Food and Agricultural Organization: The Assessment of the Socio-Economic Impacts of Climate Change at Household Level and Policy Implications. Vol. 18, No.3, pp. 6-10

FAO (2018). Impacts of climate change on fisheries and aquaculture Synthesis of current knowledge, adaptation and mitigation options, FAO Fisheries and Aquaculture Technical Paper ISSN 2070-7010 627.

FDF, (2018): Federal Department of Fisheries; Quarterly Bulletin. Vol.15, pp. 10-29

Gelles, G.M \& Mitchell, D.W. (2006), "Returns to Scale and Economies of Scale: Further Observations," Journal of Economic Education. Vol. 27, pp. 259-261.

IPCC, (2010). Intergovernmental Panel on Climate Change: The Scientific Basis. Report of Working Group I of the Intergovernmental Panel on Climate Change, Geneva. Available online: http://www.ipcc.ch.

Kareem, R. O., Dipeolu, A. O., Aromolaran, A. B. \& Williams, S. B. (2016). Economic Efficiency in Fish Farming: Hope for Agro-Allied Industries in Nigeria. Chinese Journal of Oceanology and Limnology. Vol. 26, No.1, pp. 104-115

Kariuki, S \& Mwangi, M (2015). Factors determining adoption of new agricultural technology by smallholder

farmers in developing countries. Journal of Economics and Sustainable Development, Vol. 6, No. 5, pp. $208-221$. Krull, D.S. (2014). Introduction to Psychology; Kona Publishing and Media Group: Charlotte, North Carolina.

Mayo, D (2016). Population Growing but US Farm Acreage Declining. Ag in the News, Economics, Educational Training, Farm Succession, General Agriculture, Workshop. IFAS Extension, University of Florida.

NBS, (2017). National Bureau of Statistics: www.nationalbureauofstatistics.ng.org

Niyongabire, E. \& Rhinane, H. (2019). Geospatial Techniques Use for Assessment of Vulnerability to Urban Flooding in Bujumbura City, Burundi. The International Archives of the Photogrammetry, Remote Sensing and Spatial Information Sciences, Volume XLII-4/W12, 2019 5th International Conference on Geoinformation Science

GeoAdvances 2018, 10-11 October 2018, Casablanca, Morocco. Available online: Https:/Www.Researchgate.Net/Publication/331355731_Geospatial_Techniques_Use_for_Assessment_of_ Vulnerability_to_Urban_Flooding_in_Bujumbura_City_Burundi [accessed Sep 01 2020].

Nursey-Bray, M.; Pecl, G.T.; Frusher, S.; Gardner, C.; Haward, M.; Hobday, A.J.; Jennings, S.; Punt, A.E.; Revill, H\& van Putten, I. (2012). Communicating climate change: Climate change risk perceptions and rock lobster fishers, Tasmania. Mar. Policy, Vol. 36, pp.753-759.

Olarinde, L.O. \& Kuponiyi F.A. (2014): Resource Productivity among Fish Farmers in Oyo State, Nigeria: Implications for Agricultural Development. Journal of Sustainable Development, Vol. 1, No. 1, pp. $20-26$.

Olukoya, O. (2016). The Agricultural Sector and Nigeria's Development; Comparative Perspectives from the Brazilian

Agro-industrial Economy, 1960-2015. Federal Ministry of Agricultural and Water Resources, Abuja, Nigeria, Vol. 5,No. 2, pp. 23-34.

Omonijo A.G., Oguntoke O \& Matzaraki A. (2014). Relevenca of Thermal Environment to Human Health. A Case Study of Ondo State, Nigeria. Journal of Theoretical and Applied Climatology, Vol. 113, pp. 201-212

Omotosho J. B. (2012). Pre-rainy Season Moisture Build-up and Storm Precipitation Delivery in the West African Sahel. International Journal of Climatology, Vol. 34, No. 17, pp. 67-78.

Oyetade, O \& Applanaidu, S. D. (2014). Effect of Agricultural Sector Determinants on Economic Growth. Australian Journal of Basic and Applied Sciences, Vol. 8, No. 8, pp. 68-72.

Perroni, E (2017). Five Indigenous Farming Practices Enhancing Food Security. Published by Food tank. Available online: https://www.resilience.org/stories/2017-08-14/five-indigenous-farming-practices-enhancing-foodsecurity/

Shikha, S. S. (2018). Biotechnology for Sustainable Agriculture. Emerging Approaches and Strategies. Woodhead Publishing. pp 207-234. https://doi.org/10.1016/B978-0-12-812160-3.00007-6

Thompson, O. A. (2017). Assessment of Maize Farming Household's Vulnerability to Climate Change in Southwest, Nigeria. Journal of Meteorology and Climate Science, Vol. 15, No. 1, pp. 9-19.

Thompson, O. A. \& Amos T. T (2017). Farmers' Perception of Climate Change in Southern Guinea Savannah and 
Rainforest Agro-Ecological Zone of Southwest Nigeria. Journal of Agriculture, Institute for Agricultural Research and Training. Obafemi Awolowo University, Ife, Nigeria, Vol. 25, No. 2, pp. 81-109 